\title{
Improvement of forward linkage to sustain the global apparel market of Bangladesh
}

\begin{abstract}
Forward linkages that mean activities to move the business forward play a vital role to expand global "Ready-Made Garments" (RMG) business in Bangladesh. In the global apparel market, product order is placed where additional prospects are available. The competitor countries are always trying to get the business position in world apparel market. To beat the competitor countries Bangladesh RMG sector is passing a very crucial situation. As a result, to sustain in business the sector is facing many challenges day by day because the lack of forward linkages. In this case, most of the industries have no research and development section; also have no grander marketing strategy. Overseas workforces are controlling the major part of management, production and engineering of the garment industries. The purpose of the study is to identify the present status of forward linkages of Bangladesh's RMG sector and to overcome the condition. The reduction and growth rate of garment factories, employment and export of RMG can be analyzed by looking at the main apparel item which is t-shirt and its export in nine different EU countries and by doing the analysis of the unsustainability in this business arena of Bangladesh. The study contains the present condition of RMG business, forward linkages of RMG sector, how to solve the barriers and find out some effective opportunities to meet the demand and expand the RMG business to sustain in the world market. Enhancement of the activities for moving forward and local workforce will overcome those challenges as well as expand this business.
\end{abstract}

Keywords: challenges, readymade garments industry, forward linkage, strategy formulation, sustainability
Volume 4 Issue 3 - 2018

\section{ATM Mohibullah, Umme Magreba Takebira Farhana Jannat, Imrul Kayes Shakil, Imtiaz Hossan Abir, Mosharof Hosen}

Department of Apparel Manufacture \& Technology, BGMEA University of Fashion and Technology, Bangladesh

Correspondence: Mohibullah ATM, Assistant Professor, Department of Apparel Manufacture and Technology, BGMEA University of Fashion and Technology (BUFT), Dhaka, Bangladesh,Tel (92-333) 9124l46,Email mohib@buft.edu.bd

Received: May 12, 2018 | Published: June 042018

\section{Introduction}

The ready-made garments (RMG) industry is the main source of foreign exchange earning in Bangladesh. Bangladesh held the second place in exporting ready-made garments after China in the world RMG market. ${ }^{1}$ However, Bangladesh is in the second position but it is providing only $6.4 \%$ of total demand where China is providing $36.4 \%{ }^{2}$ The two countries have an enormous difference because Bangladesh still faces the problems of backward and forward linkages. This report mainly focuses on the importance of improvement of forward linkage to sustain the global apparel market. However, making profit is the main subject matter of business but the business helps to get rid of unemployment using local workforces to develop the country. The business develops so rapidly with new consumers with new demand. Consequently, to achieve strong growth the RMG sector requires satisfactory improvement of the management, production and engineering activities to move the business consequently. The lack of researcher, developer, engineer and manager and the proper trained workers who are related to production are generating the biggest challenge for RMG business. As a result, the country is unable to produce the new categories product with high quality. In the last ten years, the reduction and growth rate of garment factories, employment, export of RMG main apparel items t-shirt in nine different EU countries show the un-sustainability in this business arena. The purpose of this study is, to find out the cause of unsustainability by analyzing the inadequacy of forward linkage and its effect. The study finds out the method to lengthen with competitive global RMG market by describing the present situation of forward linkage and finding the future opportunities in this sector.

\section{Literature review}

Most of the employer who is employed in garments industries does not have apparel manufacturing and textile-based education. In that case, proper education is a very important part. For lack of strong marketing strategy, the RMG sector has been suffering from the beginning long. If they take some strong and effective marketing policies, then the business can easily expand in the international market. Most of the workers employed in the garments industries are unskilled so their product often becomes of lower quality. However, quality is a very important thing of a product. Not only these, there are some other factors which are very important to expand the garments business. If we are able to expand the business, then the industries will have more order and earn more that will help our economic grow. In present time, the number of competitors is increasing day by day. Therefore, it is very important to improve ourselves to survive and go forward in the international market. Today Bangladesh ready-made garments sector is huge. It started from Just 47 factories in the 1982's and more than 3500 today. ${ }^{3}$ However, two years ago, the world was shocked as the RANA PLAZA COMPLEX collapsed with thousands of workers and more than thousands of lives were lost. The central bank of Bangladesh announced a huge amount counted \$500 million of low-cost financing to contribute improving the country's readymade garments sector's sustainable technologies and practices. ${ }^{4}$ After struggling in the industry, they are contribution to rebuilding a country and which is now single biggest export earner for Bangladesh. The RMG sector accounts for $80.81 \%$ of total export earnings of the country in last fiscal year 2016-2017. ${ }^{5}$ We have more than 4482 factories and about 2000 in Vietnam. China is very strong in their technology; India is a great supplier of all kind of raw materials and finished fabrics. India has a great GSP facility. Recently Vietnam and Cambodia are raising their business with raw materials and using seaport. Sri-Lanka has modern facilities, machinery, skilled work force, raw materials etc. Availability of skilled manpower and upgraded technology will prove to be a great competitor. 
In the same time, we do not have enough modern technology to meet the buyers' requirements. On the other hand, China and India have enough modern technologies. At the present, RMG market is extremely competitive for our country. At the same time, RMG competitors are increasing so fast. The RMG sector of Bangladesh is facing the tough competition from China, India, and Vietnam etc. as the competition provides the business great challenges to run in present and sustain in future.

\section{Methodology}

The secondary data was collected from Bangladesh Garment Manufacturers and Exporters Association report to ascertain the reduction rate of garment factories, employment, export of RMG main apparel items t-shirt in different EU countries Austria, Belgium, Ireland, Cyprus, Hungary, Latvia, Malta, Slovakia and Croatia in order to find out the unsustainable condition. The study also analyzed competitive study on forward linkage with others Asian countries to sort out the main reason of unsteady condition.

The study was established to confine the present condition of the forward linkages effect in RMG business of Bangladesh. It was carried out primary research by mix method approaches to collect qualitative data. The semi-structural interview- one to one, face to face, telephone interviews and via email provided the major problems in the RMG business and its solutions to sustain. Rating questionnaire was designed to collect opinion data. By identifying the research components, elements, themes and issues a theoretical framework and conceptual framework model was developed. In order to develop sustainability in RMG business with improving forward linkage, we used the random sampling from all over garment factories in Bangladesh. Lack of information we assumed half of the factory tried to develop their linkage to sustain $(\mathrm{p}=0.5$ and $\mathrm{q}=1-\mathrm{p})$, it provided the maximum variability. We wanted $90 \%$ confidence which level gives us $Z$ values of 1.645 and an $8 \%$ of error.

$$
n_{0}=\frac{z^{2} p q}{e^{2}}
$$

$$
\begin{gathered}
n_{0}=\frac{\left((1.645)^{2}(0.5)(0.5)\right)}{(0.08)^{2}} \\
n_{0}=106
\end{gathered}
$$

The 106 garment factories in our target population provided enough confidence levels for this study. According to the report of Bangladesh Garment Manufacturers and Exporters Association, the number of garment factories is 4482 (2016-17) in this population size (N) had been calculated to adjust the sample size (n) 103 Ready Made Garment Factory in Bangladesh.

\section{Data analysis}

$$
n=\frac{n_{0}}{1+\frac{\left(n_{0}-1\right)}{N}}
$$

The Table 1 represents 4482 garment factories in 2016-17 where employment of workers was 4 million, total export of total RMG 28149.84million US\$, the main apparel items t-shirt exported from Bangladesh 5861.98MN. US\$. On the other hand, in 2015-16 the number of garment factories was 154 fewer than 2016 but in that year t-shirt exported 6118.53MN. US\$ with same employment. The number of factories was more than 2016-17 in 2010 to 2012 it enhanced the employment. Already 1394 factories were closed from 2013 for different issues.

The Table 2 demonstrates the last three years' decrease rate of Bangladesh's RMG Export in EU country Austria, Belgium and Ireland as of 3.54, 31.52 and 36.64Million US\$ for knit garments. Table 3 shows drop off Bangladesh's RMG Export in EU country Cyprus, Hungary and Latvia from 2015 to 2017 and also Table 4 for EU country Malta, Slovakia and Croatia.

Table I Number of Garment Factories, Employment, Export of RMG, Main Apparel Items (T-Shirt) Exported From Bangladesh (2007-2017)

\begin{tabular}{lllll}
\hline Year & $\begin{array}{l}\text { Number of } \\
\text { garment factories }\end{array}$ & $\begin{array}{l}\text { Employment in } \\
\text { million workers }\end{array}$ & $\begin{array}{l}\text { Export of RMG (In } \\
\text { Million US\$) }\end{array}$ & $\begin{array}{l}\text { Main apparel items T-shirt exported } \\
\text { from Bangladesh (Value in MN. US\$) }\end{array}$ \\
\hline $2007-08$ & 4743 & 2.8 & 10699.8 & 2765.56 \\
$2008-09$ & 4925 & 3.5 & 12347.77 & 3065.86 \\
$2009-10$ & 5063 & 3.6 & 12496.72 & 3145.52 \\
$2010-11$ & 5150 & 3.6 & 17914.46 & 4696.57 \\
$2011-12$ & 5400 & 4 & 19089.73 & 4713.11 \\
$2012-13$ & 5876 & 4 & 21515.73 & 5143.22 \\
$2013-14$ & 4222 & 4 & 24491.88 & 5863.81 \\
$2014-15$ & 4296 & 4 & 25491.4 & 6064.13 \\
$2015-16$ & 4328 & 4 & 28094.16 & 6118.53 \\
$2016-17$ & 4482 & 4 & 28149.84 & 5861.98 \\
\hline
\end{tabular}

Data Source Export Promotion Bureau Compiled by BGMEA 
Table 2 Bangladesh's RMG Export to Austria, Belgium and Ireland 2015 to 2017 (value in Million US\$)

\begin{tabular}{llll}
\hline EU Countries & Knit & & \\
\hline & 2015 & 2016 & 2017 \\
Austria & 27.19 & 29.16 & 23.65 \\
Belgium & 412.99 & 432.72 & 381.47 \\
Ireland & 121.81 & 115.44 & 85.17 \\
\hline
\end{tabular}

Table 3 Bangladesh's RMG Export to Cyprus, Hungary and Latvia 2015 to 2017 (value in Million US\$)

\begin{tabular}{llll}
\hline EU Countries & Knit & & \\
\hline & 2015 & 2016 & 2017 \\
Cyprus & 1.82 & 1.47 & 1.27 \\
Hungary & 3.94 & 3.23 & 1.83 \\
Latvia & 2.6 & 1.35 & 1.03
\end{tabular}

Table 4 Bangladesh's RMG Export to Malta, Slovakia and Croatia 2015 to 2017 (value in Million US\$)

\begin{tabular}{llll}
\hline EU Countries & Knit & & \\
\hline & 2015 & 2016 & 2017 \\
Malta & 4.8 & 3 & 3.59 \\
Slovakia & 45.63 & 43.42 & 45.01 \\
Croatia & 9.06 & 9.62 & 8.93 \\
\hline
\end{tabular}

Source: EPB, Compiled by: RDTI Cell, BGMEA

The backward linkage of India and China is much stronger than other countries in the region because the most important raw materials of textile-clothing industry is fiber, both the countries can satisfy $100 \%$ of their demand through domestic production and also exports to the global market including other Asian countries. ${ }^{6}$ Bangladesh is deeply dependent on imported fiber from China and India. If the forward linkages are higher than average, it implies that the relative importance of output from this industrial sector is higher. ${ }^{7}$ When imported components are deducted and only domestic components are considered, China holds for forward linkage that is highest among the comparing countries. ${ }^{6}$ Semi structured interview and rating questionnaire provide the issues of challenging situation and elements of conceptual framework. The responders were strongly agreed for research and development, create sustainable business model, product design, consumer analysis. The responders are working on different international knit and woven clothing brand. Therefore, they have no opportunity to develop individual design and to create demand, after sales service, mutual and good relation makes the production cycle.

Bangladesh specializes in high-volume; low-cost production of technically simple garments and utilizes the world's largest low-cost labor pool, which allows subcontracting from lead contractors to complete orders on time at a lower price per unit than lead contractors. ${ }^{8}$ The retailers and distributors are the ones who perform the demand forecasting and play the key role. ${ }^{6}$

\section{Result and discussion}

The number of garment factories had increased gradually from 2007 to 2013 and dropped down in 2014 which is dramatically dropped from 2007 and the number of factories stabilized up to 2017. The employment of workers has also remained constant. Export of RMG plateaued at 2007 to 2010 and increased rapidly up to 2012 . The growth of total RMG export value gradually increased at 2013 and sharply increased from 2014 to 2016 but in 2017 was dropped gradually. Main apparel items t-shirt exported from Bangladesh also slowly increased at 2011 from its stabilized position. From that time, it was slightly fluctuated and again fell slowly from its constant level (Figure 1).

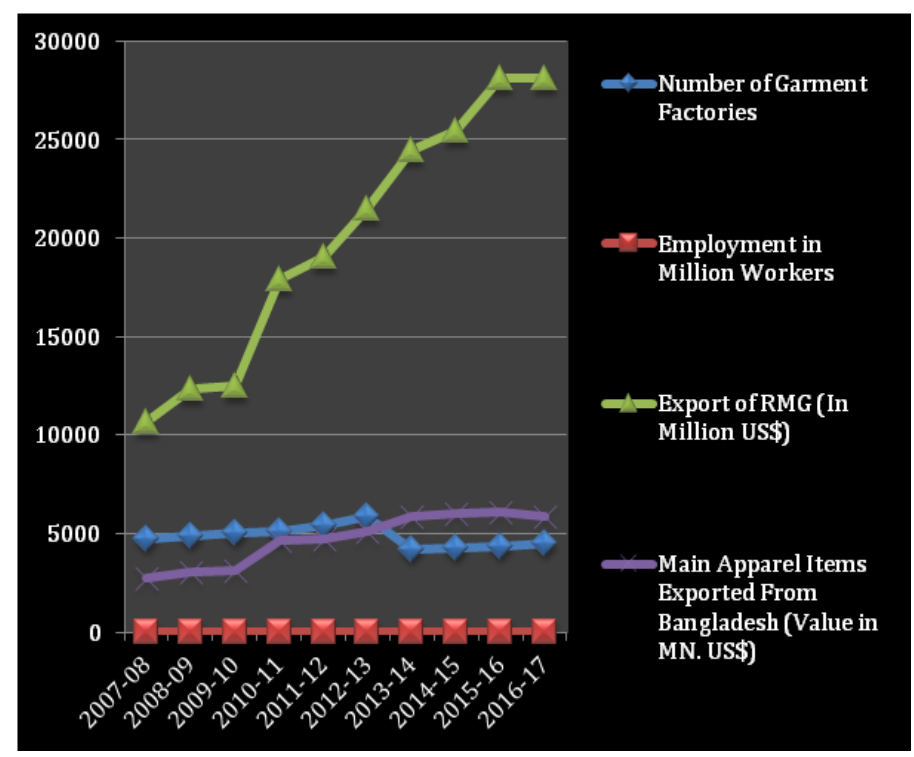

Figure I Number of garment factories, employment, export of RMG, main apparel items (t-shirt) exported from Bangladesh (2007-20I7).

Figures 2-4 demonstrate the last three years' sharp and slow dropped rate of Bangladesh's RMG Export in nine EU countries Austria, Belgium, Ireland, Cyprus, Hungary, Latvia, Malta, Slovakia and Croatia for knit garments. The decreasing rate provides the findings of the study. It generally shows that Bangladesh is currently facing the apparel business challenges and it will be very difficult to sustain in the business field.

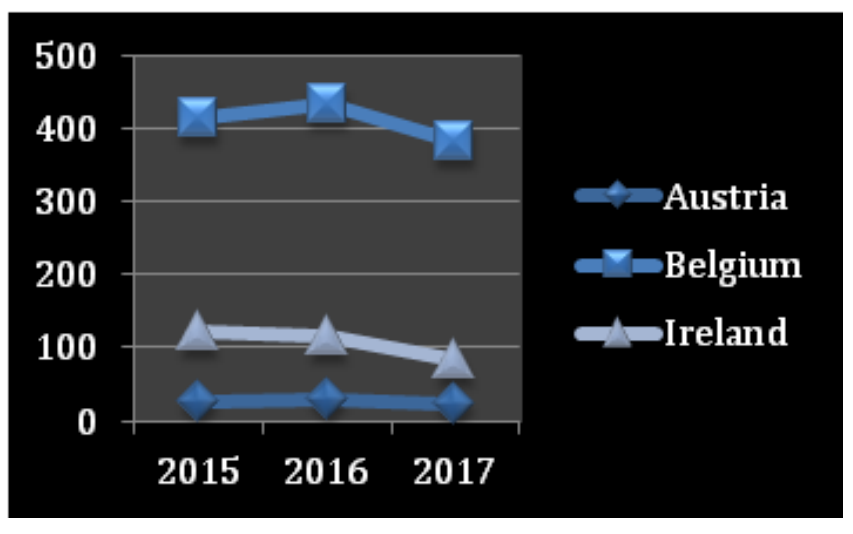

Figure 2 Bangladesh's RMG Export to Austria, Belgium and Ireland from 2015 to 2017 .

\section{Forward linkage in Bangladesh}

“Contribution of RMG sector in the country's export earnings is increasing day by day as the government has taken various steps to 
improve overall workplace safety and compliance in RMG sector" a Bangladesh Bank official told BSS (Bangladesh Sangbad Sangstha). According to Bangladesh bank data, export earnings from RMG stood at $\$ 7,628.67$ million during the October to December quarter of 2017 which was $\$ 7,043.8$ million in the same quarter of 2016. During the October to December period, export earnings from RMG sector increased by 6.78percent or $\$ 484.55$ million than the previous quarter (July-September) in 2017. RMG is the major export item, which was 82.4percent of the country's total export earnings of $\$ 9253.29$ million in the October to December quarter. ${ }^{9}$ And Bangladesh Garments Manufacturing and Exporters Association (BGMEA) have set a target to earn 50billion USD from RMG export by $2021 .{ }^{10}$ The elements of forward linkages, such as Government support, marketing, research and demand analysis, education, research and development, training, foreign employee, product quality, individual design and to create demand, mutual relations, after sales service etc. will reach on that target (Figure 5).

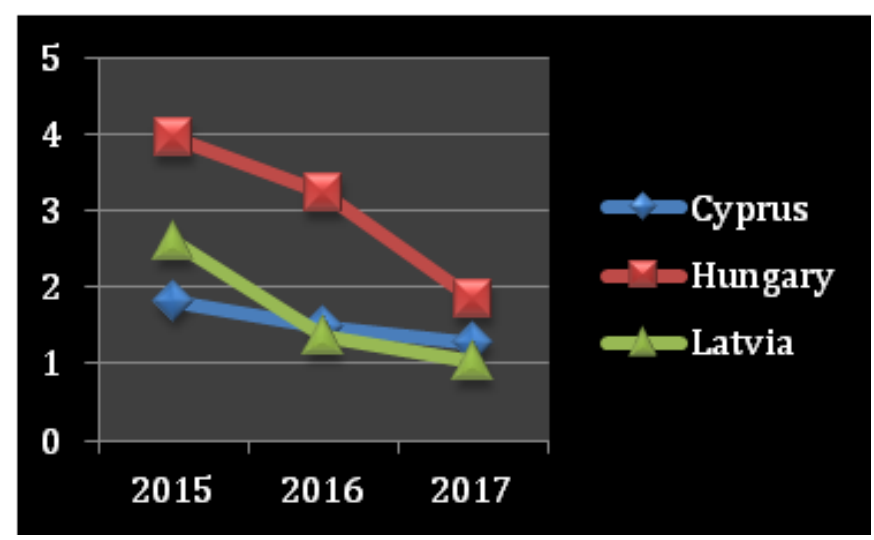

Figure 3 Bangladesh's RMG Export to Cyprus, Hungary and Latvia from 2015 to 2017.

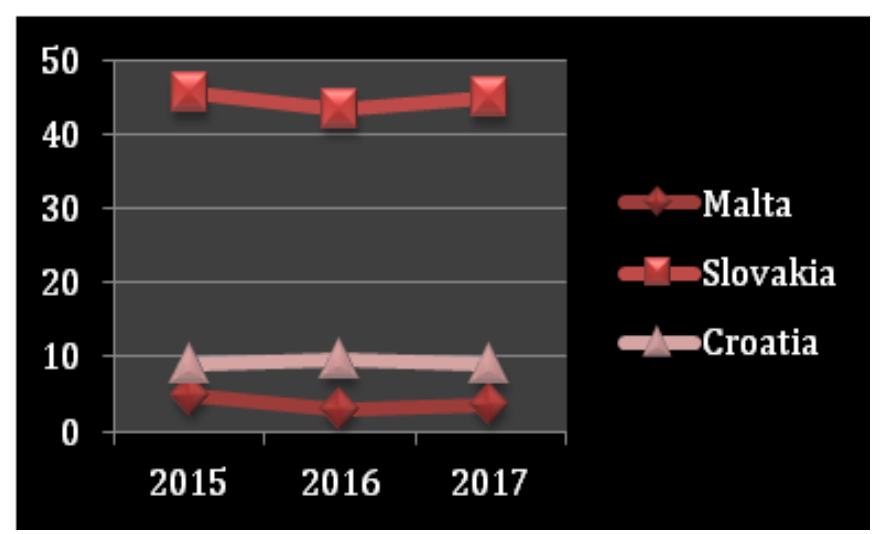

Figure 4 Bangladesh's RMG Export to Malta, Slovakia and Croatia from 2015 to 2017 .

Bangladesh is now one of the 12 largest apparel exporters of the world, the sixth largest supplier in the US market and the fifth largest supplier of T-shirts in the EU market. ${ }^{3}$ By this sector, we are getting $84 \%$ of export earns. However, the business is facing diverse types of challenges for expanding their business. If we can see, Europe has 1 percent bank interest rate, while our interest rate is 12 percent. "This is the biggest obstacle to growth of business". Now, we are a developing country in the world. We have a $\$ 6.70$ billion-dollar industry, while the global market is worth 600billion dollars. ${ }^{11}$ So, we can easily to say that we have an immense opportunity to go ahead. In this stage, the government facilities would be prepared as insightful for the business to sustain the global market. The tax-free agreement with another country would be also a great support for the RMG industry. To build a relationship with other countries, government investments are necessary for this sector. Transportation system is also a main problem for convening product to the seaport. By working together with government, employer, and workers organizations, international organizations, brand and retailers will expand the sector. In the majority of the factory expected in structural fire and building safety by the Accord, Alliance and Government effort to precede trained worker, occupational safety and health.

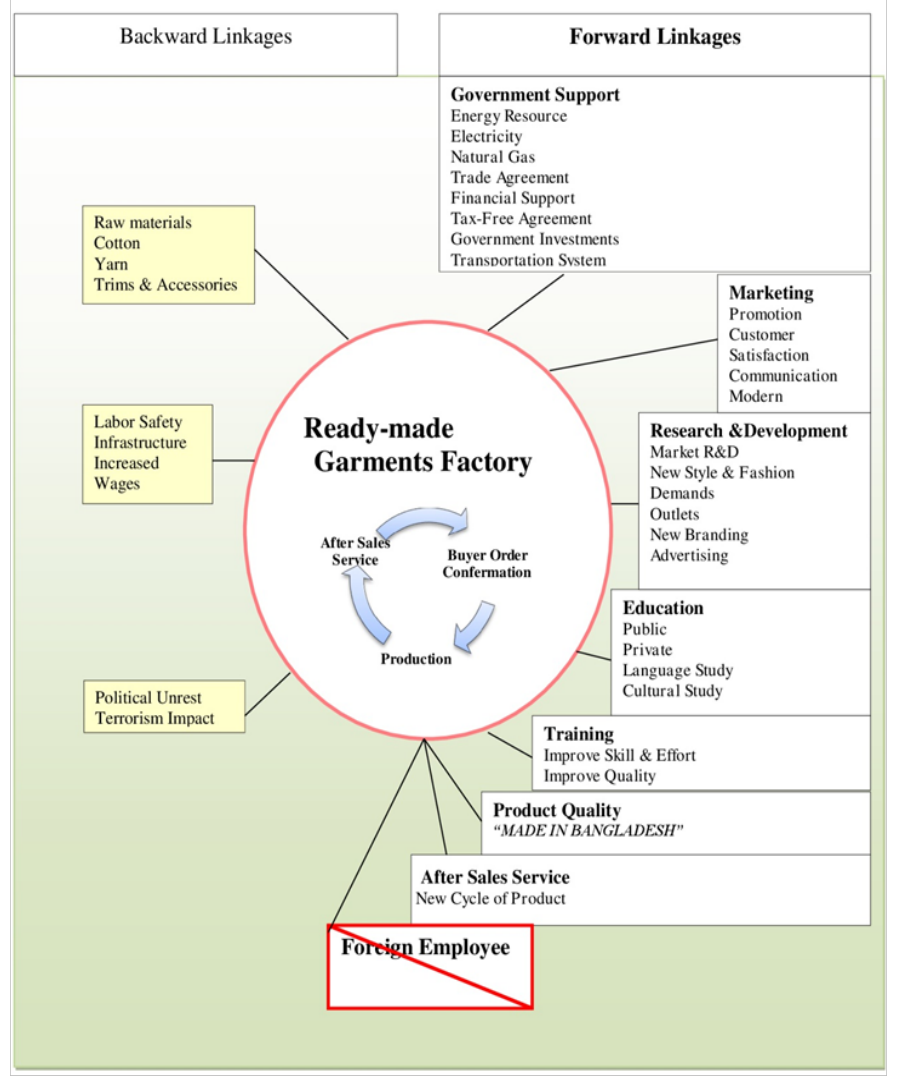

Figure 5 Conceptual framework models of Backward Linkage and Forward Linkage.

This is an industry with strong foundation with legislation to rebuild more budget, stuff and skill. In this time, 300 new trade unions formed for compensation loan and system for the brighter future. The government support is greatly needed for generating an organization or industry to spread their business. To fulfill the buyers' demand Bangladeshi government has taken a great decision about it. Proper supply of electricity of and natural gas RMG industry is also a great prospect to more production for every industry. The only use of electricity will be enormous cost for every industry. In the same time, enough facility of gas, the production cost would be reduced in a maximum. So, the elements of Government Facilitate industry through the duty-free importing of raw materials, cash incentives, Government investments, transportation system, the electricity, natural gas duty drawbacks, back-to-back credit, bonded warehouses etc. 


\section{Marketing of the RMG}

RMG marketing is an immensely vital function. The manufacturers do not equally distribute their product worldwide. Some of the marketers they are marketing global trading with is the main reason for more tax paying. However, not every country is paying same tax; they are doing business with other countries for minimum or free tax. RMG industries of Bangladesh need to follow the global fashion trend. International fashion show, exhibition, conference for innovation as it would provide the opportunities to cope up. Actually, some of the effective promotional activities will help our RMG marketing for share global market such as fashion show, trade show, visual merchandising, factory outlet, discount offer for etc. Factory outlet and design studio would be obviously better for our future RMG marketing. Bangladesh is the second largest global exporter of RMG. The industry has a longterm vision of entering the international market by capitalizing its expertise and experience in retail marketing. The language and culture both are most important part of better customer response. Sufficient marketing knowledge and experience are helpful for proper way of marketing. By segmenting at geographic locations, we will be able to have our strong market presence systematically and homogeneously. Marketing is a major research part of the RMG industry of Bangladesh. During making plan for starting, a business then tries to find out the marketing barriers of this business. While determining the marketing barriers then find out the way to remove this. Actually, marketing will be dependent on some of $4 \mathrm{ps}$ as like; product, price, promotion and place. These are interrelated for marketing strategies. The product is the basic tools of marketing after propagation of a product than the major part is reaching this product to actual buyers or customers. Still RMG business depends on good buyer or customer response. It is possible when we are fulfilling the buyer requirements. Customer satisfaction is at the center of all marketing functions. So, the desire to maximize customer satisfaction led the firms to implement better marketing practices.

\section{Education}

Education is one of the important human rights. Education in Apparel Manufacturing, Merchandising, Textile, Fashion and Industrial Engineering, Human Resource Management etc. plays a vital role to improve manpower skill, enhancing industrial productivity, improve the product quality. Without education it is impossible to expand the business, survive in the competitive market, and meet the demand of the worldwide customer. Government support and public university and research center will improve the sector like design, innovation, and fashion research.

\section{Research and development (R\&D)}

Research and Development is the only one process by which a company works to obtain new knowledge that might be used to create new technologies, products or services and marketplace. R\&D section plays a very important role in RMG industry for the overall production, quality, fashion and style. The task of the R\&D section starts from the fabrication and ends it at finish product. In garment industry, $\mathrm{R} \& \mathrm{D}$ department works on latest trend and demands of worldwide customer. Creation of a new design, style will find more buyer attraction and possibility of higher market share. Opening outlets in major world cities, new branding and advertising will enhance more the business worldwide. Energetic, efficient, strong academic background and multi-dimensional research associates from core subjects like economics, international tread, environmental economics, science and social welfare are the core strength of research and development. Ensuring a research ethics for policy orientation to analyzing the current policies in the aspect of Bangladesh garment sector to facilitate the organization on upcoming policy suggestion is also one of the strengths. Receiving different high-end training related WTO, rules of origin, international tread; research methodology and modeling research associates became highly skilled and efficient for development. Different national and international seminars to disseminate the knowledge of different scientific and empirical research finding on a regular basis will also help to grow.

\section{Training}

Training is a program that helps people to learn specific knowledge and skills to improve performance in their current job. Good training and development always help to retain right people and make profit. In textile and RMG sector of our country, most of the workers are unskilled, for that reason their outcome is not so good. As a result, our product is not high-quality product. Our garment market is still categorized as a source of low medium quality garment in international market. It is one of the big challenges for our RMG sector to sustain in international market. It is a hard fact that our RMG sector has been suffering a lack of skilled workforce. Training is necessary for the development of the product quality and to sustain in global market. Training is a process of teaching and learning a specific task. By use of training an unskilled worker can easily understand his/her job and do better performance.

\section{Obtain position of overseas employee}

Most of the companies' employee is from out of the country for top management in Bangladesh garments industry. The overseas employees are attending in various countries to attend buyer meetings and international seminars. Using foreign employees is not appalling at all but intimidation is that most of the overseas employees are from India or Srilanka. The disadvantages are that these countries are competitor in international market and the employee from these countries are permanent. Therefore, they go back to their country and start readymade garment business. So, it is a very big threat for garments sector. Local experts will reduce the foreign employee from top management position.

\section{Quality}

Quality is a very important thing for any kind of product. The importance of product quality will expand the business. In the whole country, there is a huge demand of Japanese product and this only for their quality. Same as in world market we have value for garments product and that is "MADE IN BANGLADESH". If we want to reach in top of the competition we will have to produce more qualityful products. Because quality is one of the best issues by which we can easily beat our competitors. If we can increase our quality, buyers will pay more for our product and we will be able to earn more.

\section{After sales service}

The business success depends on after sales service and customer relationship management. The new cycle of production for a new product before ending the previous cycle production would be a great opportunity to run the cycle with same buyer. Only good relation and after sales service will provide the opportunities. 


\section{Conclusion}

The RMG sector is that the strongest economic sector of Bangladesh. In times, most of the revenue is coming from the RMG incomes. This sector is directly or indirectly serving to Bangladesh to sustain in its economic commonplace. Now, this sector has become the foremost necessary earning sector of Bangladesh. So, stretching out this sector is incredibly necessary for our country. However the event is being disturbed by some weakness of forward linkage. As a result of that, we tend to face immense issues to meeting the demand of our consumers and expand the business in world RMG market. If we wish to expand our RMG business and earn additional, we must always minimize the weakness of forward linkages. So, it's very important that the responsible personnel, business leaders and the government should associate with each other to reach in the top and lead the world RMG market. The government already has taken steps about it, because of our target for 2021 is \$50billion USD export target announced. It is possible when we have enough resource of electricity and natural gas. The government has taken decision to create plants of electricity and to provide gas facility for the industry. Actually, without resources of gas, energy, solar power, capital this not possible to run any garments industry or factory. That is why; if the government takes necessary steps and that will be the greatest opportunity for this sector. In our country most of the industries do not have R\&D Department. For that reason, buyers complete this task by hiring expatriates from other. We are only manufacturing the product as like tailor shop. The focus on education and research will develop this business sector and we will obtain more opportunity to sustain in global readymade garments market.

\section{Acknowledgements}

None.

\section{Conflict of interest}

Author declares there is no conflict of interest in publishing the article.

\section{References}

1. Mirdha RU. Bangladesh remains second largest garments exporter, against all odds. Thedailystar; 2016.

2. Ovi I. Dhakatribune. Dhaka: 2A Media Ltd; 2017.

3. Rana, M. 2016.

4. Akter M. News \& analysis. Dhaka: Textiletoday; 2015.

5. Hasan SM. An Anlysis of Marketing Barriers to RMG Industry in Bangladesh. J Textile engineering \& Fashion Technology. 2018; 4(1):8.

6. Masum M. The Bangladesh Textile-Clothing Industry: A Demand-Supply Review. 2016: 109-135.

7. Hara T. Quantitative tourism industry analysis. Oxford: Elsevier Inc; 2008: 288.

8. Padmanabhan V, Baumann-Pauly D, Labowitz S. The hidden price of low cost: Subcontracting in Bangladesh's garment industry. New York: New York University; 2015.

9. Businessnews. 2018.

10. BKMEA. Research and development. 2017.

11. RMG Bangladesh. 2017. 